\title{
PERBANDINGAN INTERPOLASI DAN EKSTRAPOLASI NEWTON UNTUK PREDIKSIDATA TIME SERIES
}

\author{
Marinus Ignasius Jawawuan Lamabelawa \\ Program Studi Teknik Informatika, STIKOM Uyelindo Kupang \\ Jl. Perintis Kemerdekaan 1, Kayu Putih, Oebufu, Kupang \\ e-mail:mijlamabelawa@gmail.com
}

\begin{abstract}
For numerous purposes, time series data are analyzed to understand phenomena or behaviors of variables, and try to find future value. Interpolation is guessing time series data point between the range of data set. Extrapolation is predict or guessing time series data point from beyond the range of data set.

In this study, Newton's Extrapolation is compared with linear and squared extrapolation. Newton's Extrapolation making the assumption that the observed trend continues for values of $x$ outside the model range.

The robustness of prediction using Root Mean Square Error (RMSE) and Mean Average Percentage Error (MAPE). The results of newton's interpolation with bottom, middle, and top approaches found the best value are middle approach, namely RMSE 76,01 and MAPE 4,65\%. In Newton's Extrapolation, the error values are consistent at bottom, middle, and top approaches, namely RMSE 541,170 anda MAPE 33,19\%.

Based on data from the Statistics of Indonesia on the percentage and number of poor people in East Nusa Tenggara Province in 2010 -2018 is declining trend pattern. The error value with Linear, Quadratic, and Newton's Extrapolation shows the robust value results at linear or trend extrapolation, namely RMSE 157,450 and MAPE 7,93\%. These results indicate Newton's extrapolation works well on non-linear data and requires a combination method with soft computing methods such as Fuzzy Systems, AG, or ANN.
\end{abstract}

Keywords:time series, poverty data, newton interpolation, newtonextrapolation

\section{PENDAHULUAN}

Interpolasi dapat didefinisikan sebagai teknik untuk mendapatkan suat fungsi dekatan yang meliwati semua titik dari sebuah set data diskrit atau dapat didefinisikan sebagai teknik perkiraan suatu titik atau nilai diantara titik-titik diskrit atau suatu set data yang telah diketahui. Teknik ini memiliki dua pendekatan yaitu mencari titik tengah yang disebut interpolasi dan dapat diperluas dengan membuat perkiraan titik ujung setelah set data yang terdefinisi atau titik selanjutnya dari titik-titik yang sudah diketahui disebut ekstrapolasi[1].

Model-model metode interpolasi diantaranya interpolasi linear, interpolasi kuadrat, dan interpolasi beda terbagi newton. Model perluasan ekstrapolasi yang telah dilakukan pada [2] adalah ekstrapolasi linear dan kuadrat. Fokus pembahasan pada penelitian ini adalah mengembangkan model Ekstrapolasi beda terbagi Newton yang diturunkan dari perumusan Interpolasi Newton.Selanjutnya dibandingkan model Ekstrapolasi Newton dengan Ekstrapolasi Linear dan Kuadrat terhadap data runtun waktu penduduk miskin Provinsi Nusa Tenggara Timur(NTT) yang merupakan lanjutan dari penelitian [2], [3].

Pertimbangan menggunakan Data time series penduduk miskin NTT seperti pada Tabel 1 yang diakses secara daring [4] dan secara grafis ditunjukkan pada Gambar 1 karena merupakan isu utama yang menjadi prioritas program Pemda NTT saat ini. Secara nasional urutan penduduk miskin NTT berada pada peringkat bawah diatas urutan 20 . Untuk itu fokus Pemda Propinsi NTT adalah terus berjuang menurunkan peringkat kemiskinan, dimana target maksimal dalam 5 tahun berikut berada pada rangking 10 besar.

Tabel 1. Data Penduduk Miskin NTT(ribu jiwa) sumber: BPS NTT

\begin{tabular}{ccc}
\hline No & Tahun & Data penduduk miskin \\
\hline 1 & 1996 & 1264,20 \\
2 & 1997 & 1368,30 \\
3 & 1998 & 1431,40 \\
4 & 1999 & 1632,70 \\
5 & 2000 & 1295,70 \\
6 & 2001 & 1239,60 \\
7 & 2002 & 1206,50 \\
8 & 2003 & 1165,90 \\
9 & 2004 & 1152,10 \\
10 & 2005 & 1171,20 \\
11 & 2006 & 1273,90 \\
12 & 2007 & 1163,60 \\
13 & 2008 & 1105,80 \\
14 & 2009 & 1021,80 \\
15 & 2010 & 1020,60 \\
16 & 2011 & 986,50 \\
17 & 2012 & 1000,30 \\
18 & 2013 & 1006,90 \\
19 & 2014 & 994,68 \\
20 & 2015 & 1159,84 \\
21 & 2016 & 1149,92 \\
22 & 2017 & 1150,79 \\
23 & 2018 & 1142,17 \\
\hline & &
\end{tabular}




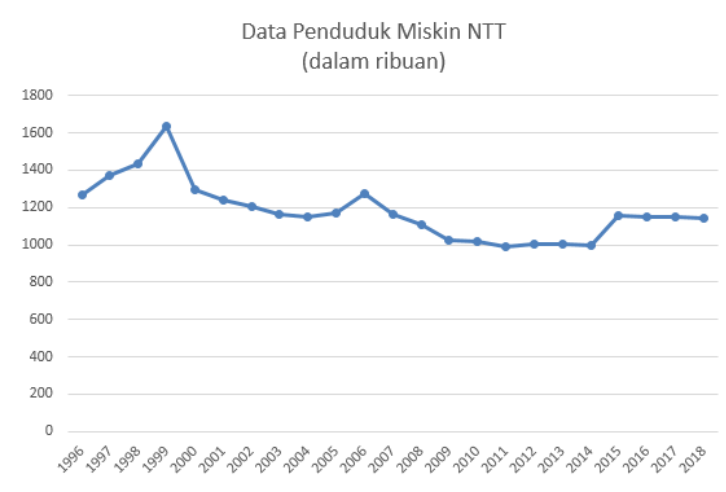

Gambar 1. Grafik penduduk miskin NTT periode $1996-2018$

Beberapa penelitian yang mengkaji model-model interpolasi dan ekstrapolasi telah dilakukan pada pada tahun 2013 oleh [5] tentang Peramalan Produksi Ubi Kayu Propinsi Jawa Tengah Menggunakan Algoritma Ekstrapolasi Newton. Penelitian oleh [1] tentang pengaplikasian metode interpolasi dan ekstrapolasi Lagrange, Chebysevev, dan Spline kubik untuk prediksi angka pengangguran di Indonesia oleh Pratama, dkk. Penelitian oleh [6] pada tahun 2015 tentang model matematika untuk ekstrapolasi penduduk Ghana dengan menerapkan Newton's Devided Difference Formula, Penelitian tahun 2018 oleh [7] dengan membandingkan metode Lagrange dan Newton pada interpolasi polinomial dalam mengestimasi harga saham.

Untuk menguji akurasi dari ketepatan perkiraan data dengan interpolasi, dapat dilakukan pengukuran perbandingan nilai kehandaan prediksi dengan nilai akar dari rata-rata kuadrat error atau Root Mean Square Error (RMSE) dan akurasi prediksi(accuracy) dengan nilai persentasi dari ratarata relatif error atau Mean Average Percentage Error (MAPE) seperti telah dilakukan pada [2].

\section{METODE PENELITIAN}

Metode-metode yang mendukung dalam kegiatan penelitian ini dijelaskan sebagai berikut:

\subsection{Dasar-dasar Prediksi Time Series}

Data runtun waktu atau data time series oleh Makridakis, dkk pada [2] adalah jenis data yang dikumpulkan menurut urutan waktu dalam suatu rentang waktu tertentu. Tipe data time series oleh Render dan Hanna pada [2] yaitu: data Trend (T), Siklus (Cycles/ C), Musiman (Seasonality/S), dan pola Random variation (Irregular/I).

Data-data penduduk miskin disusun berdasarkan periode runtun waktu (time series) dapat dianalisis dengan metode komputasional yang salah satunya adalah metode prediksi. Prediksi adalah proses-proses perkiraan tentang sesuatu yang akan terjadi pada masa depan berdasarkan historis data yang ada. Tujuannya mengurangi ketidakpastian dan membuat perkiraan lebih baik dari apa yang akan terjadi di masa depan seperti yang dilakukan oleh [2].
Beberapa penelitian yang telah dilakukan berhubungan dengan kemiskinan yakni Penelitian [8] tentang Evaluasi Kinerja Program Pengentasan Kemiskinan (Studi Program Anti Kemiskinan Bidang Pertanian di Kabupaten Tuban), dan penelitian oleh [9] berkaitan dengan Pemodelan Data Panel Kemiskinan di Provinsi NTT dengan GEE dan GLMM.

\subsection{Interpolasi}

Teknik interpolasi yang digunakan untuk menganalisis data kemiskinan adalah interpolasi linear, interpolasi kuadrat, dan interpolasi linear, yang diuraikan sebagai berikut:

\section{1) Interpolasi linear}

Interpolasi linear adalah fungsi memperkirakan nilai suatu nilai tengah atau titik tengah yang didefinisikan dengan $\mathrm{F}(\mathrm{X})$ dari dua nilai yang telah diketahui yakni nilai sebelumnya $\mathrm{F}\left(\mathrm{X}_{0}\right)$ dan nilai sesudahnya $F\left(X_{1}\right)$. Sedangkan ekstrapolasi linear adalah mencari titik ujung yakni $F\left(X_{1}\right)$ dari nilai yang diketahui, yakni titik $\mathrm{F}\left(\mathrm{X}_{0}\right)$ sebagai titik awal dan $\mathrm{F}(\mathrm{X})$ sebagai titik tengah yang dirumuskan sebagai berikut:

$$
\begin{aligned}
& f_{1}(X)=f\left(X_{0}\right)+\frac{f\left(X_{1}\right)-f\left(X_{0}\right)}{\left(X_{1}-X_{0}\right)}\left(X-X_{0}\right) \ldots \ldots \\
& f\left(X_{1}\right)=f\left(X_{0}\right)+\frac{f_{1}(X)-f\left(X_{0}\right)}{\left(X-X_{0}\right)}\left(X_{1}-X_{0}\right) \ldots
\end{aligned}
$$

Dimana:

$X_{0}$ :Titik atau nilai awal

$X_{1}$ :Titik atau nilai ujung

$X_{1}$ :Titik yang akan dicari nilai fungsi

$f\left(X_{0}\right)$ : Nilai fungsi dari titik atau nilai awal

$f\left(X_{1}\right)$ : Nilai fungsi dari titik ujung

$f_{1}(X)$ : Nilai fungsi yang dari titik yang dicari

\section{2) Interpolasi kuadrat}

Perluasan dari interpolasi linear adalah interpolasi kuadrat adalah penyempurnaan dari interpolasi linear seperti pada [2]. Jika pada interpolasi linear membutuhkan dua nilai, maka pada interpolasi kuadrat digunakan tiga nilaiuntuk mencari satu nilai. Dimisalkanyakni $\mathrm{X}_{0}, \mathrm{X}_{1}$, dan $\mathrm{X}_{2}$ dengan nilai fungsi yakni $\mathrm{F}\left(\mathrm{X}_{0}\right), \mathrm{F}\left(\mathrm{X}_{1}\right), \mathrm{F}\left(\mathrm{X}_{2}\right)$ untuk memperkirakan nilai suatu fungsi atau nilai tengah yang didefinisikan dengan $F(X)$ dari nilai titik $X$ yang telah diketahui.Perumusan interpolasi dan ekstrapolasi kuadrat diuraikan sebagai berikut:

$f(x)=b_{0}+b_{1}\left(x-x_{0}\right)+b_{2}\left(x-x_{0}\right)\left(x-x_{1}\right) \ldots$

Dimana:

$b_{0}=F\left(X_{0}\right)$

$b_{1}=\frac{f\left(x_{1}\right)-f\left(x_{0}\right)}{\left(x_{1}-x_{0}\right)}$

$b_{2}=\frac{\frac{f\left(X_{2}\right)-f\left(X_{1}\right)}{X_{2}-X_{1}}-\frac{f\left(X_{1}\right)-f\left(X_{0}\right)}{\left(X_{1}-X_{0}\right)}}{X_{2}-X_{0}}$. 
Untuk mencari titik ujung yakni $\mathrm{F}\left(\mathrm{X}_{2}\right)$ dapat diuraikan dari $b_{2}$ pada (6) dan oleh Lamabelawa (2017) didapat dapat dicari nilai ekstrapolasi kuadratyang diuraikan dari (3), dimana untuk mendapatkan nilaif $\left(X_{2}\right)$ yang didalamnya ada $\mathrm{c} 1$ dan b1 dapat diuraikan sebagai berikut:

$$
\begin{array}{r}
c 1=\left[\frac{f(x)-b_{0}-b_{1}\left(x-x_{0}\right)}{\left(x-x_{0}\right)\left(x-x_{1}\right)}\right] . \\
f\left(X_{2}\right)=f\left(X_{1}\right)+\left[\left[b 1+c 1\left(X_{2}-X_{0}\right)\right]\left(X_{2}-X_{1}\right)\right] \ldots
\end{array}
$$

\section{3) Interpolasi Newton}

Fokus pada penelitian ini adalah mencari titik ujung dengan menguraikan interpolasi Newton menjadi ekstrapolasi Newton yang merupakan perluasan dari interpolasi linear dan kuadrat seperti Lamabelawa (2017), dimana titik yang dicari dihitung dari semua titik yang diketahui dengan perumusan umum polinomial derajat $n$ adalah:

$\mathrm{F}_{\mathrm{n}}(\mathrm{X})=\mathrm{b}_{0}+\mathrm{b}_{1}\left(\mathrm{x}-\mathrm{x}_{0}\right)+. .+\mathrm{b}_{\mathrm{n}}\left(\mathrm{x}-\mathrm{x}_{0}\right)\left(\mathrm{x}-\mathrm{x}_{1}\right) . .\left(\mathrm{x}-\mathrm{x}_{\mathrm{n}-1}\right) \ldots \ldots(9)$

Dimana :

$$
\begin{aligned}
\mathrm{b}_{0} & =\mathrm{F}\left(\mathrm{x}_{0}\right) \ldots \ldots \ldots \ldots \ldots \ldots \ldots \ldots \ldots \ldots \ldots \ldots \\
\mathrm{b}_{1} & =\mathrm{F}\left[\mathrm{x}_{1}, \mathrm{x}_{0}\right] \ldots \ldots \ldots \ldots \ldots \\
\mathrm{b}_{2} & =\mathrm{F}\left[\mathrm{x}_{2}, \mathrm{x}_{1}, \mathrm{x}_{0}\right] \ldots \ldots \ldots \ldots \\
\mathrm{b}_{\mathrm{n}} & =\mathrm{F}\left[\mathrm{x}_{\mathrm{n}}, \mathrm{x}_{\mathrm{n}-1}, \ldots, \mathrm{x}_{0}\right]
\end{aligned}
$$

\section{a. Perhitungan orde 1}

$$
\begin{aligned}
& F\left[X_{1}, X_{0}\right]=\frac{F\left(X_{1}\right)-F\left(X_{0}\right)}{\left(X_{1}-X_{0}\right)} \\
& F\left[X_{2}, X_{1}\right]=\frac{F\left(X_{2}\right)-F\left(X_{1}\right)}{\left(X_{2}-X_{1}\right)} \\
& F\left[X_{3}, X_{2}\right]=\frac{F\left(X_{3}\right)-F\left(X_{2}\right)}{\left(X_{3}-X_{2}\right)}
\end{aligned}
$$

b. Perhitungan orde ke-2

$$
\begin{aligned}
& F\left(X_{3}, X_{2}, X_{1}\right)=\frac{F\left(X_{3}, X_{2}\right)-F\left(X_{2}, X_{1}\right)}{\left(X_{3}-X_{1}\right)} \\
& F\left(X_{2}, X_{1}, X_{0}\right)=\frac{F\left(X_{2}, X_{1}\right)-F\left(X_{1}, X_{0}\right)}{\left(X_{2}-X_{0}\right)}
\end{aligned}
$$

c. Perhitungan orde ke-3

$$
F\left(X_{3}, X_{2}, X_{1}, X_{0}\right)=\frac{F\left(X_{3}, X_{2}, X_{1}\right)-F\left(X_{2}, X_{1}, X_{0}\right)}{\left(X_{3}-X_{0}\right)}
$$

\section{4) Ekstrapolasi Newton}

Untuk mencari titik ujung dari sejumlah titik-titik yang diketahui, merupakan hasil subsitusi dari interpolasi newtonyang dimisalkan interpolasi newton orde 3 yang diuraikan sebagai berikut:

$F_{x}=b_{0}+b_{1}\left(X-X_{0}\right)+b_{2}\left(X-X_{0}\right)\left(X-X_{1}\right)+$ $b_{3}\left(X-X_{0}\right)\left(X-X_{1}\right)\left(X-X_{2}\right)$

Titik ujung atau $F\left(X_{3}\right)$ termuat dalam $b_{3}$ dan diuraikan sebagai berikut:

$$
b_{3}=
$$

$\frac{F_{X}-\left(b_{0}+b_{1}\left(X-X_{0}\right)+b_{2}\left(X-X_{0}\right)\left(X-X_{1}\right)\right)}{\left(X-X_{0}\right)\left(X-X_{1}\right)\left(X-X_{2}\right)}$
Dimisalkan rumus b3 dipecah menjadi 2 yakni pembilang dan penyebut yang disubsitusi:

$$
\begin{aligned}
b_{3 p 1}= & F_{X}-\left(b_{0}+b_{1}\left(X-X_{0}\right)+b_{2}(X-\right. \\
& \left.\left.X_{0}\right)\left(X-X_{1}\right)\right) \ldots \ldots \ldots \ldots \ldots \ldots \ldots \ldots \ldots \ldots \ldots \ldots \ldots \ldots \ldots \ldots \ldots \ldots \ldots
\end{aligned}
$$

Maka

$$
\frac{\frac{\left(\mathrm{F}\left(\mathrm{X}_{3}, \mathrm{X}_{2}\right)-\mathrm{F}\left(\mathrm{X}_{2}, \mathrm{X}_{1}\right)\right)}{\left(\mathrm{X}_{3}-\mathrm{X}_{1}\right)}-\frac{\left(\mathrm{F}\left(\mathrm{X}_{2}, \mathrm{X}_{1}\right)-\mathrm{F}\left(\mathrm{X}_{1}, \mathrm{X}_{0}\right)\right)}{\left(\mathrm{X}_{2}-\mathrm{X}_{0}\right)}}{\left(\mathrm{X}_{3}-\mathrm{X}_{0}\right)}=\frac{b_{3 p 1}}{b_{3 p 2}} .
$$

$\frac{F\left(X_{3}, X_{2}\right)-F\left(X_{2}, X_{1}\right)}{\left(X_{3}-X_{1}\right)}-\frac{F\left(X_{2}, X_{1}\right)-F\left(X_{1}, X_{0}\right)}{\left(X_{2}-X_{0}\right)}=\frac{b_{3 p 1}}{b_{3 p 2}}\left(X_{3}-\right.$

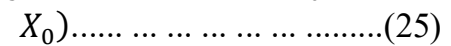

$$
\frac{F\left(X_{3}, X_{2}\right)-F\left(X_{2}, X_{1}\right)}{\left(X_{3}-X_{1}\right)}=F\left(X_{2}, X_{1}, X_{0}\right)+\frac{b_{3 p 1}}{b_{3 p 2}}\left(X_{3}-\right.
$$$$
\left.X_{0}\right)
$$

$$
\begin{array}{r}
F\left(X_{3}, X_{2}\right)-F\left(X_{2}, X_{1}\right)=\left[F\left(X_{2}, X_{1}, X_{0}\right)+\right. \\
\left.\frac{b_{3 p 1}}{b_{3 p 2}}\left(X_{3}-X_{0}\right)\right]\left(X_{3}-X_{1}\right) \ldots \ldots \ldots \ldots \\
F\left(X_{3}, X_{2}\right)=F\left(X_{2}, X_{1}\right)+\left[\left[F\left(X_{2}, X_{1}, X_{0}\right)+\right.\right. \\
\left.\left.\frac{b_{3 p 1}}{b_{3 p 2}}\left(X_{3}-X_{0}\right)\right]\left(X_{3}-X_{1}\right)\right] \ldots \ldots \ldots . . .
\end{array}
$$

$$
\frac{F\left(X_{3}\right)-F\left(X_{2}\right)}{\left(X_{3}-X_{2}\right)}=F\left(X_{2}, X_{1}\right)+\left[\left[F\left(X_{2}, X_{1}, X_{0}\right)+\right.\right.
$$$$
\left.\left.\frac{b_{3 p 1}}{b_{3 p 2}}\left(X_{3}-X_{0}\right)\right]\left(X_{3}-X_{1}\right)\right]
$$

$$
\begin{aligned}
& \frac{F\left(X_{3}\right)-F\left(X_{2}\right)}{\left(X_{3}-X_{2}\right)}=\left[F\left(X_{2}, X_{1}\right)+\left[\left[F\left(X_{2}, X_{1}, X_{0}\right)+\right.\right.\right. \\
& \left.\left.\left.\frac{b_{3 p 1}}{b_{3 p 2}}\left(X_{3}-X_{0}\right)\right]\left(X_{3}-X_{1}\right)\right]\right] \text {. }
\end{aligned}
$$

$$
\begin{aligned}
& F\left(X_{3}\right)-F\left(X_{2}\right)=\left[F\left(X_{2}, X_{1}\right)+\left[\left[F\left(X_{2}, X_{1}, X_{0}\right)+\right.\right.\right. \\
& \left.\left.\left.\frac{b_{3 p 1}}{b_{3 p 2}}\left(X_{3}-X_{0}\right)\right]\left(X_{3}-X_{1}\right)\right]\right]\left(X_{3}-X_{2}\right) \ldots \ldots \ldots \ldots(31)
\end{aligned}
$$




$$
\begin{aligned}
& F\left(X_{3}\right)=F\left(X_{2}\right)+\left[\left[F\left(X_{2}, X_{1}\right)+\left[\left[F\left(X_{2}, X_{1}, X_{0}\right)+\right.\right.\right.\right. \\
& \left.\left.\left.\frac{b_{3 p 1}}{b_{3 p 2}}\left(X_{3}-X_{0}\right)\right]\left(X_{3}-X_{1}\right)\right]\right]\left[\left(X_{3}-X_{2}\right)\right] \ldots \ldots \text { (32) }
\end{aligned}
$$

\subsection{Kriteria Pemilihan Metode Terbaik}

Untuk membandingkan tingkat kehandalan dan akurasi ketiga metode interpolasi seperti pada [2] dan [6]digunakan metode evaluasi sebagai berikut:

1) Root Mean Square Error(RMSE)

Akar dari rata-rata kuadrat error atau RMSE digunakan untuk membandingkan berbagai data aktual dengan data yang ditaksir atau diprediksi.Rumusan nilai RMSE sebagai berikut:

$$
R M S E=\sqrt{\frac{\sum_{t=1}^{n}\left(X_{t}-\bar{X}_{t}\right)^{2}}{n}}=\sqrt{\frac{\sum_{t=1}^{n} e_{t}^{2}}{n}} .
$$

dimana $n$ menyatakan jumlah data dan $e_{t}$ adalah nilai kesalahan dari $X_{t}-\hat{X}_{t} . X_{t}$ adalah nilai data aktual dan $\hat{X}_{t}$ adalah nilai hasil interpolasi.

\section{2) Mean Absolute Percentage Error(MAPE)}

Persentase dari rata-rata relatif error atau MAPE adalah teknik menentukan akurasi dari model prediksi dengan mengambil rata-rata dari kesalahan absolut dibandingkan dengan data aktualterhadap nilai persentasi $100 \%$. Perumusan MAPE adalah:

$$
M A P E=\frac{\sum_{t=1}^{n}\left|\frac{e_{t}}{X_{t}}\right|}{n} \times 100
$$

dimana $n$ adalah jumlah data dan $e_{t}$ adalah nilai kesalahan taksiran yang diperoleh dari $X_{t}-\hat{X}_{t}$. Nilai data aktual dinotasikan dengan $X_{t}$ dan $\hat{X}_{t}$ adalah nilai hasil interpolasi.

\subsection{Prosedur Penelitian}

Prosedur penelitianadalah sebagai berikut:

\section{A. Tempat Penelitian}

Data-data runtun waktudiambil melalui media daring dari website BPS NTT yakni http://ntt.bps.go.id.

\section{B. Populasi dan Sampel}

Populasi adalah data runtun waktu penduduk miskin Propinsi NTT yang dihimpun BPS per kabupaten, dengan sampling sejumlah23 data dari tahun 1996 sampai 2018 melanjutkan sampel yang telah diambil oleh penelitian [2] dan [3].

\section{Langkah-Langkah Penelitian}

Langkah-langkahperhitungan interpolasi yang dikembangkan adalah sebagai berikut:

a) Akuisisi data runtun waktu.

b) Tabulasi data dan disimpan secara array.

c) Prediksi dengan ekstrapolasi linear serta hitung performansi prediksi dengan RMSE dan MAPE. d) Prediksi dengan ekstrapolasi kuadrat serta hitung performansi prediksi dengan RMSE dan MAPE.

e) Prediksi dengan ekstrapolasi Newton serta hitung performansi prediksi dengan RMSE dan MAPE.

f) Bandingkan performansi prediksi metode Newton dengan Linear dan Kuadrat.

\section{HASIL DAN DISKUSI}

Setelah melakukan uji cobaterhadap metode interpolasi dengan menggunakan data runtun waktu penduduk miskin dari tahun 1996-2018yang dikembangkan dari [2] hasilnya sebagai berikut:

a) Ekstrapolasi Linear

Berikut adalah hasil perhitungan ekstrapolasi tahun 2019 dengan data aktual tahun 2017,2018 yang dipetakan secara grafis terlihat pada Gambar 2 menggunakan Persamaan (2) dan Data Tabel 1 sebagai berikut:

$$
\begin{gathered}
f(2019)=f\left(X_{0}\right)+\frac{f(X)-f\left(X_{0}\right)}{\left(X-X_{0}\right)}\left(X_{1}-X_{0}\right) \\
f(2019)=1150,79+\frac{(1142,17-1150,79)}{(2018-2017)}(2019-2017) \\
f(2019)=1133,55 \\
\text { Ekstrapolasi }
\end{gathered}
$$

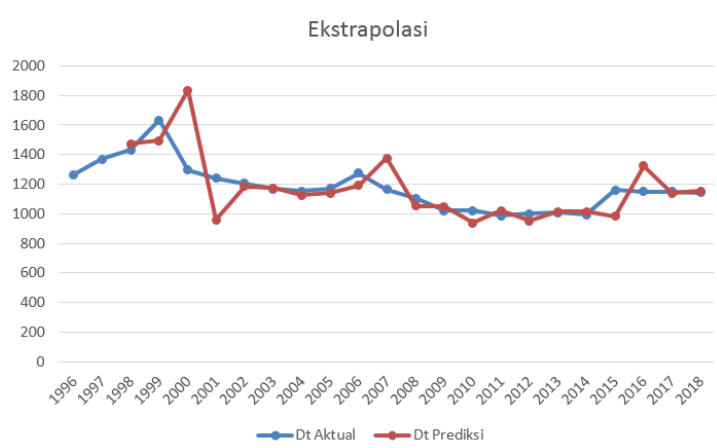

Gambar 2. Grafik perbandingan data aktual dengan hasil Ekstrapolasi Linear

b) Ekstrapolasi kuadrat

Perhitungan ekstrapolasi kuadrat menggunakan 3 data sebelumnya yakni $\mathrm{X}_{0}: 2016, \mathrm{X}_{1}: 2017, \mathrm{X}: 2018$ dan merujuk pada Persamaan(7) dan (8)dan nilai titik yang dicari adalah $X_{2}: 2019$. Nilai- nilai fungsi yang diketahui adalahF $\left(\mathrm{X}_{0}\right): 1149,92 ., \mathrm{F}\left(\mathrm{X}_{1}\right)$ : 1150,79 ., $F(X): 1142,17$. Selanjutnya nilai $b_{0}$ dari (3), Nilai b1 dari (4), dan nilai c1 dari (7) yakni:

$$
\begin{aligned}
& b_{0}=1149,92 \\
& b_{1}=\frac{(1150,79-1149,92)}{(2017-2016)}=0,87
\end{aligned}
$$


$c 1=\left[\frac{f(x)-b_{0}-b_{1}\left(x-x_{0}\right)}{\left(x-x_{0}\right)\left(x-x_{1}\right)}\right]$

$c_{1}=\frac{1142,17-1149,92-0,87(2018-2016)}{(2018-2016)(2018-2017)}$

$c_{1}=\frac{-7,75-1,74}{2}=-4,745$

Jadi hasil ekstrapolasi kuadrat dengan pendekatan atas dari Persamaan (8) adalah: $f(x)=1150,79+$ $[[0,87+-4.745(2018-2016)](2018-2017)$

$f(x)=1150,79+[0,87+(-9,49)](1)$

$f(x)=1142,17$

Hasil perhitungan lengkap ekstrapolasi kuadrat pendekatan atas dapat dilihat secara grafis Gambar 3.

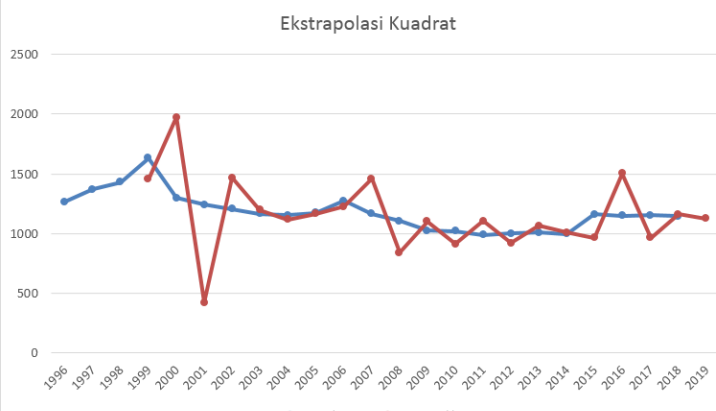

Gambar 3. Grafik perbandingan data aktual dengan hasil ekstrapolasi kuadrat pendekatan atas

c) Interpolasi Newton

Perhitungan interpolasi newton menggunakan Persamaan (9) yang diuraikan seperti pada Persamaan (10) sampai (19) dengan perhitungan dimulai pada orde 1,2, dan 3 yang digunakan untuk menghitung orde 4 , dan seterusnya tergantung jumlah data set dan orde yang didefinisikan.

Pada perhitungan ini diambil Perhitungan ekstrapolasi kuadrat menggunakan 3 data sebelumnya yakni $\mathrm{X}_{0}: 2014, \mathrm{X}_{1}: 2015, \mathrm{X}: 2016$, $\mathrm{X}_{2}: 2017, \mathrm{X}_{3}: 2018$ dan nilai titik yang dicari adalah $X: 2016$.

Nilai-nilai fungsi yang diketahui adalahF $\left(\mathrm{X}_{0}\right)$ :994,68.,F( $\left.\mathrm{X}_{1}\right): \quad$ 1159,84., $\quad \mathrm{F}(\mathrm{X})$ : $1149,92 ., F\left(X_{2}\right): 1150,79 ., F\left(X_{3}\right): 1142,17$., dengan hasil sebagai berikut:

Hasil perhitungan orde 1 sesuai (14),(15),(16) yakni:

$\mathrm{F}\left[\mathrm{X}_{1}, \mathrm{X}_{0}\right]=\frac{\mathrm{F}\left(\mathrm{X}_{1}\right)-\mathrm{F}\left(\mathrm{X}_{0}\right)}{\left(\mathrm{X}_{1}-\mathrm{X}_{0}\right)}=\frac{1159.84-994.68}{(2015-2014)}=165,16$

$F\left[X_{2}, X_{1}\right]=\frac{1150.79-1159.84}{(2017-2015)}=-4,53$

$F\left[X_{3}, X_{2}\right]=\frac{F\left(X_{3}\right)-F\left(X_{2}\right)}{\left(X_{3}-X_{2}\right)}=-8,62$

Perhitungan orde ke-2 sesuai (17) dan (18) adalah:

$$
\begin{gathered}
F\left(X_{3}, X_{2}, X_{1}\right)=\frac{F\left(X_{3}, X_{2}\right)-F\left(X_{2}, X_{1}\right)}{\left(X_{3}-X_{1}\right)}=\frac{-8,62-(-4,53)}{(2018-2015)}=-1,37 \\
F\left(X_{2}, X_{1}, X_{0}\right)=\frac{-4,53-(165,16)}{(2017-2014)}=-56,56
\end{gathered}
$$

Hasil perhitungan orde ke-3 sesuai (19) adalah:
$\mathrm{F}\left(\mathrm{X}_{3}, \mathrm{X}_{2}, \mathrm{X}_{1}, \mathrm{X}_{0}\right)=\frac{\mathrm{F}\left(\mathrm{X}_{3}, \mathrm{X}_{2}, \mathrm{X}_{1}\right)-\mathrm{F}\left(\mathrm{X}_{2}, \mathrm{X}_{1}, \mathrm{X}_{0}\right)}{\left(\mathrm{X}_{3}-\mathrm{X}_{0}\right)}=\frac{-1,37-(-56,56)}{(2018-2014)}=13,80$

Hasil perhitungan taksiran tahun 2016 dengan interpolasi newton orde 3 sesuai Persamaan 9 diperoleh hasil sebagai berikut:

$\mathrm{F}_{\mathrm{n}}(\mathrm{X})=\mathrm{b}_{0}+\mathrm{b}_{1}\left(\mathrm{x}-\mathrm{x}_{0}\right)+\mathrm{b}_{2}\left(\mathrm{x}-\mathrm{x}_{0}\right)\left(\mathrm{x}-\mathrm{x}_{1}\right)+\mathrm{b}_{3}\left(\mathrm{x}-\mathrm{x}_{0}\right)\left(\mathrm{x}-\mathrm{x}_{1}\right)(\mathrm{x}-$ $\mathrm{X}_{2}$ )

$\mathrm{F}_{\mathrm{n}}(\mathrm{X})=994,68+165,16(2)+(-56,56)(2)(1)+(-$ $154,19)(2)(1)(-1)$

$\mathrm{F}_{3}(\mathrm{X})=1184,28$

Untuk perhitungan lengkap interpolasi metode newton untuk 3 pendekatan bawah, tengah, dan atas dapat dilihat pada Tabel 3 dan salah satu hasil grafik pada Gambar 4.

\begin{tabular}{|c|c|c|c|c|c|}
\hline \multicolumn{3}{|c|}{ Data $(* 1.000)$} & \multirow{2}{*}{$\begin{array}{l}\text { Pdktn } \\
\text { bawah }\end{array}$} & \multirow{2}{*}{$\begin{array}{l}\text { Pdktn } \\
\text { tengah }\end{array}$} & \multirow{2}{*}{$\begin{array}{c}\text { Pdktn } \\
\text { atas }\end{array}$} \\
\hline No & tahun & Data & & & \\
\hline 1 & 1996 & 1264,20 & & & \\
\hline 2 & 1997 & 1368,30 & 1154,38 & 1574,02 & 1418,775 \\
\hline 3 & 1998 & 1431,40 & 1805,33 & 1383,42 & 1669,625 \\
\hline 4 & 1999 & 1632,70 & 1363,43 & 1475,22 & 970,325 \\
\hline 5 & 2000 & 1295,70 & 1352,55 & 1201,70 & 1263,350 \\
\hline 6 & 2001 & 1239,60 & 1255,80 & 1195,70 & 1182,100 \\
\hline 7 & 2002 & 1206,50 & 1199,45 & 1170,60 & 1145,050 \\
\hline 8 & 2003 & 1165,90 & 1177,05 & 1144,67 & 1182,350 \\
\hline 9 & 2004 & 1152,10 & 1065,28 & 1229,08 & 1187,075 \\
\hline 10 & 2005 & 1171,20 & 1311,73 & 1180,22 & 1304,125 \\
\hline 11 & 2006 & 1273,90 & 1187,85 & 1220,97 & 1019,750 \\
\hline 12 & 2007 & 1163,60 & 1210,53 & 1074,52 & 1068,725 \\
\hline 13 & 2008 & 1105,80 & 1049,63 & 1059,25 & 964,425 \\
\hline 14 & 2009 & 1021,80 & 1070,93 & 987,85 & 1035,625 \\
\hline 15 & 2010 & 1020,60 & 986,63 & 1009,15 & 966,325 \\
\hline 16 & 2011 & 986,50 & 997,37 & 993,05 & 1017,770 \\
\hline 17 & 2012 & 1000,30 & 1052,26 & 972,26 & 1046,635 \\
\hline 18 & 2013 & 1006,90 & 869,74 & 1086,12 & 1022,675 \\
\hline 19 & 2014 & 994,68 & 1129,26 & 1070,12 & 1284,503 \\
\hline 20 & 2015 & 1159,84 & 1108,30 & 1184,28 & 1099,253 \\
\hline 21 & 2016 & 1149,92 & 1156,68 & 1334,75 & 1162,466 \\
\hline 22 & 2017 & 1150,79 & & & \\
\hline 23 & 2018 & 1142,17 & & & \\
\hline
\end{tabular}

Tabel 3. Hasil perhitungan Interpolasi Newton 


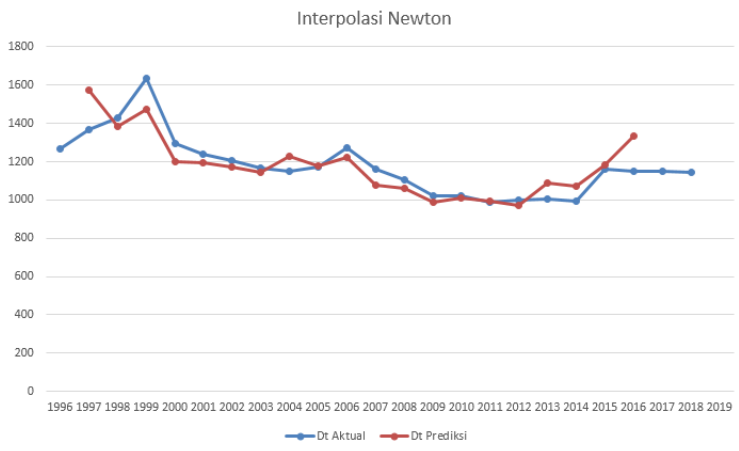

Gambar 4. Grafik perbandingan data aktual dengan hasil interpolasi Newton pendekatan tengah

Pada Tabel 4 berikut ditunjukkan perbandingan nila RMSE dan MAPE untuk pehitungan Interpolasi Newton dari ke-3 pendekatan yakni pendekatan bawa, tengah, dan atas.

Tabel 4. Perbandingan nilai RMSE dan MAPE Perhitungan Interpolasi Newton

\begin{tabular}{llrc}
\hline No. & $\begin{array}{c}\text { Interpolasi } \\
\text { Newton Orde 3 }\end{array}$ & RMSE & $\begin{array}{c}\text { MAPE } \\
\mathbf{( \% )}\end{array}$ \\
\hline 1. & Pendekatan bawah & 131,875 & 7,375 \\
2. & Pendekatan tengah & 76,010 & 4,654 \\
3. & Pendekatan atas & 188,845 & 9,065 \\
\hline
\end{tabular}

d) Ekstrapolasi Newton

Perhitungan ekstrapolasi Newton dengan menghitung nilai fungsi $\mathrm{X}_{3}$ atau $\mathrm{F}\left(\mathrm{X}_{3}\right)$ dari Persamaan (20) yang diuraikan dari Persamaan (21) sampai Persamaan (32). Sebagai contoh dihitung nilai Fungsi tahun 2019 atau F(2019) sebagai fungsi prediksi dengan menggunakan 4 data dan nilai fungsi sebelumnya yakni $\mathrm{X}_{0}=2015 ., \quad \mathrm{F}\left(\mathrm{X}_{0}\right)=1159.84$., $\mathrm{X}_{1}: 2016, \mathrm{~F}\left(\mathrm{X}_{1}\right)=1149.92 ., \quad \mathrm{X}: 2017, \mathrm{~F}(\mathrm{X})=$ $1150.79 ., X_{2}: 2018, F\left(X_{2}\right)=1142.17 ., X_{3}: 2019$.

dengan hasil sebagai berikut:

$\mathrm{F}\left[\mathrm{X}_{2}, \mathrm{X}_{1}\right]=\frac{1142.17-1149.92}{(2018-2016)}=\frac{-7.75}{2}=-3,875$

$F\left[X_{1}, X_{0}\right]=\frac{1149.92-1159.84}{(2016-2015)}=\frac{-9.92}{1}=-9,92$

$F\left(X_{2}, X_{1}, X_{0}\right)=\frac{F\left(X_{2}, X_{1}\right)-F\left(X_{1}, X_{0}\right)}{\left(X_{2}-X_{0}\right)}=\frac{-3,875-(-9,92)}{(2018-2015)}=2,02$

Hasil perhitungan berdasarkan Persamaan (32) adalah:

$F\left(X_{3}\right)=1142.17+\left[\left[-3,875+\left[\left[2,02+\frac{6,76}{-2}(4)\right](3)\right]\right](1)\right]$

$F\left(X_{3}\right)=1103,78$

Hasil lengkap perhitungan Ekstrapolasi Linear, kuadrat, dan Newton terlihat pada Tabel 5.

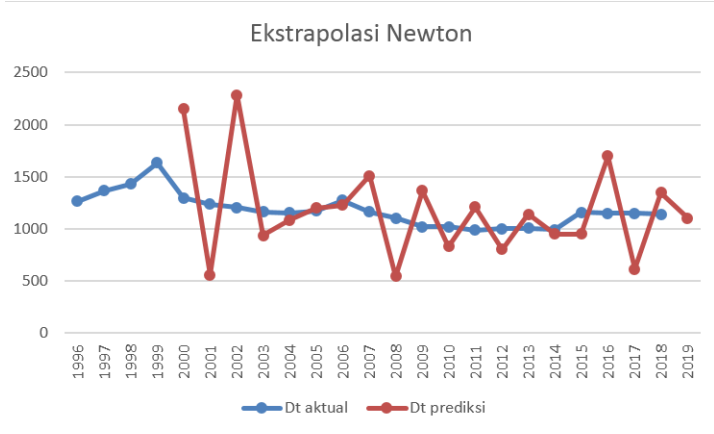

Gambar 5. Grafik perbandingan data aktual dengan hasil EkstrapolasiNewton pendekatan tengah

Setelah dilakukan perhitungan ekstrapolasi newton dari tahun 2000 sampai tahun 2019 dengan menggunakan empat data sebelumnya 1996-1999 secara berturut-turut terhadap tiga tipe pendekatan yakni pendekatan bawah, tengah, dan pendekatan atas didapat nilai yang sama dan konsisten pada ke-3 pendekatan tersebut yang terlihat pada Tabel 6 .

Gambar 5 diatas adalah perbandingan grafis pola data aktual dan pola data hasil prediksi dengan ekstrapolasi Newton.

Tabel 5. Hasil perhitungan Ekstrapolasi Linear, Kuadrat, dan Newton

\begin{tabular}{|c|c|c|c|c|c|}
\hline \multicolumn{3}{|c|}{ Data $(* 1.000)$} & \multirow[t]{2}{*}{ Linear } & \multirow[t]{2}{*}{ Kuadrat } & \multirow[t]{2}{*}{ Newton } \\
\hline No & tahun & Data & & & \\
\hline 1 & 1996 & 1264,20 & & & \\
\hline 2 & 1997 & 1368,30 & & & \\
\hline 3 & 1998 & 1431,40 & 1472,40 & & \\
\hline 4 & 1999 & 1632,70 & 1494,50 & 1390,40 & \\
\hline 5 & 2000 & 1295,70 & 1834,00 & 1770,90 & 2151,40 \\
\hline 6 & 2001 & 1239,60 & 958,70 & 757,40 & 256,10 \\
\hline 7 & 2002 & 1206,50 & 1183,50 & 1520,50 & 2283,60 \\
\hline 8 & 2003 & 1165,90 & 1173,40 & 1229,50 & 938,50 \\
\hline 9 & 2004 & 1152,10 & 1125,30 & 1158,40 & 1087,30 \\
\hline 10 & 2005 & 1171,20 & 1138,30 & 1178,90 & 1199,40 \\
\hline 11 & 2006 & 1273,90 & 1190,30 & 1204,10 & 1229,30 \\
\hline 12 & 2007 & 1163,60 & 1376,60 & 1357,50 & 1510,90 \\
\hline 13 & 2008 & 1105,80 & 1053,30 & 950,60 & 543,70 \\
\hline 14 & 2009 & 1021,80 & 1048,00 & 1158,30 & 1366,00 \\
\hline 15 & 2010 & 1020,60 & 937,80 & 995,60 & 832,90 \\
\hline 16 & 2011 & 986,50 & 1019,40 & 1103,40 & 1211,20 \\
\hline 17 & 2012 & 1000,30 & 952,40 & 953,60 & 803,80 \\
\hline 18 & 2013 & 1006,90 & 1014,10 & 1048,20 & 1142,80 \\
\hline 19 & 2014 & 994,68 & 1013,50 & 999,70 & 951,20 \\
\hline 20 & 2015 & 1159,84 & 982,46 & 975,86 & 952,02 \\
\hline 21 & 2016 & 1149,92 & 1325,00 & 1337,22 & 1698,58 \\
\hline 22 & 2017 & 1150,79 & 1140,00 & 974,84 & 612,46 \\
\hline
\end{tabular}




\begin{tabular}{|c|c|c|c|c|c|}
\hline \multicolumn{3}{|c|}{ Data $(* 1.000)$} & \multirow[t]{2}{*}{ Linear } & \multirow[t]{2}{*}{ Kuadrat } & \multirow[t]{2}{*}{ Newton } \\
\hline No & tahun & Data & & & \\
\hline 23 & 2018 & 1142,17 & 1151,66 & 1161,58 & 1348,32 \\
\hline 24 & 2019 & & 1133,55 & 1132,68 & 1103,78 \\
\hline
\end{tabular}

Tabel 6. Perbandingan nilai RMSE dan MAPE Perhitungan Ekstrapolasi Newton

\begin{tabular}{cccc}
\hline No. & $\begin{array}{c}\text { Ekstrapolasi } \\
\text { Newton Orde 3 }\end{array}$ & RMSE & $\begin{array}{c}\text { MAPE } \\
\text { (\%) }\end{array}$ \\
\hline 1. & Pendekatan bawah & 541,17 & 33,185 \\
2. & Pendekatan tengah & 541,17 & 33,185 \\
3. & Pendekatan atas & 541,17 & 33,185 \\
\hline
\end{tabular}

e) Perhitungan nilai RMSE dan MAPE

Pada bagian ini dilakukan perhitungan untuk perbandingan perhitungan nilai RMSE dan MAPE dari ke-3 metode interpolasi yang merujuk pada Persamaan (30) dan (31) ditunjukkan pada Tabel 7.

Tabel 7. Perbandingan nilai RMSE dan MAPE

Perhitungan Ekstrapolasi Linear, Kuadrat, Newton

\begin{tabular}{clrr} 
No. & Ekstrapolasi & RMSE & $\begin{array}{c}\text { MAPE } \\
\mathbf{( \% )}\end{array}$ \\
\hline 1. & Linear & 157,450 & 7,930 \\
2. & Kuadrat & 202,908 & 12,268 \\
3. & Newton & 541,170 & 33,185 \\
\hline
\end{tabular}

\section{KESIMPULAN}

Simpulan dari penelitian ini adalah:

1) Hasil perhitungan nilai interpolasi dibandingkan dengan nilai sebenarnya tergantung pola data time series. Dengan perhitungan RMSE dan MAPE yang menunjukan variasi nilai yang berbeda pada model data trend dan musiman.

2) Pada perhitungan dengan Interpolasi Newton menggunakan pendekatan bawah, tengah, dan atas ditemukan nilaiterbaik dengan pendekatan tengah yakni RMSE 76,01 dan MAPE 4,65\%.

3) Pada perhitungan dengan Ekstrapolasi Newton yang merupakan perluasan dari Interpolasi Newton dihasilkan nilai error yang konsisten pada pendekatan bawah, tengah, dan atas yakni nilai RMSE 541,170 dan nilai MAPE 33,19\%.

4) Pada data runtun waktu penduduk miskin NTT berpola trend menurun, perhitungan prediksi dengan ekstrapolasi linear, kuadrat, dan newton menunjukkan nilai error terbaik pada Ekstrapolasi Linear RMSE 157,450 dan nilai MAPE 7,93\%.

5) Perhitungan Interpolasidan Ekstrapolasi Newton bekerja baik pada data-data non linear dan dibutuhkan kombinasi dengan metode soft computing seperti Sistem Fuzzy, AG, atau JST.

\section{PENGHARGAAN DAN TERIMA KASIH}

Ucapan terima kasih kepada semua pihak yang sudah membantu dalam penelitian ini:

1) Mahasiswa Program Studi Teknik Informatikayang telah memberikan data melalui tugas kuliah Analisis Numerik.

2) Badan Pusat Statistik (BPS) NTT.

3) Teman-teman dosen yang memberikan saran pada diskusi dan saran-sarantentang penelitian.

4) Semua pihak yang tidak bisa disebutkan satu persatu disampaikan terima kasih.

\section{DAFTAR PUSTAKA}

[1] Pratama, R., Sianipar, R.H., Wiryajati, K., 2014, Pengaplikasian Metode Interpolasi dan Ekstrapolasi Lagrange, Chebyshev, dan Spline Kubik Untuk Memprediksi Angka Pengangguran di Indonesia, Jurnal Dielektrika, Jurusan Teknik Elektro, Universitas Mataram, 1(2), 116-121

[2] Lamabelawa, M.I.J., 2017, Analisis Perhitungan Metode Interpolasi Pada Data Time Series Kemiskinan NTT, Jurnal Hoaq - Teknologi Informasi, STIKOM Uyelindo Kupang, 8(1), 635641.

[3] Lamabelawa, M.I.J dan Soekarto, B., 2016, Pendekatan Baru Prediksi Data Kemiskinan NTT Dengan Fuzzy Time Series, Jurnal Hoaq Teknologi Informasi, STIKOM Uyelindo Kupang, 7(2), 554-561.

[4] Badan Pusat Statistik, Konsep dan metodelogi perhitungan penduduk miskin, Badan Pusat Statistik, https://www,bps,go,id, diakses 08 November 2019.

[5] Djumaty, B. L., Tanaamah, A.R., Wowor, A.D. 2013, Peramalan Produksi Ubi Kayu Propinsi Jawa Tengah Menggunakan Algoritma Ekstrapolasi Polinomial Newton, Prosiding Seminar Nasional Sistem Informasi Indonesia, SESINDO, 2-4Desember 2013, Bali, Halaman 281- 285 .

[6] Opuku-Sarkodie, R., Acheampong, E., Enu, P., Bokoum, A., Gardiner, F.A., Manu, T.A., 2015, Mathematical Model to Extrapolate the Population of Ghana: An Application of Newton's Devided Difference Formula, Asia Pasific Journal of Multidisciplinary Research[www.apjmr.com],22 Jan 2015; Unduh [2019-12-10] 3(2), 17-25.

[7] Astuti, L.W., Sudarwanto., Ambarwati, Lukito., 2018, Perbandingan Metode Lagrange dan Metode Newton pada Interpolasi Polinomial dalam Mengestimasi Harga Saham, Jurnal 
Matematika Terapan, LPM-Universitas Negeri Jakarta, 2(1), 25-35.

[8] Kurniawan, S, Wijaya, A,F, Domai, T, , 2014, Evaluasi Kinerja Program Pengentasan Kemiskinan (Studi Program Anti Kemiskinan Bidang Pertanian di Kabupaten Tuban), Jurnal Wacana, 17(3), 117-125.

[9] Anggara, D., 2015, Pemodelan Data Panel Kemiskinan di Provinsi Nusa Tenggara Timur Menggunakan GEE dan GLMM, Tesis, Prodi Statistika Terapan, Institut Pertanian Bogor, Bogor(ID). 